\title{
A BETEGEK ÁLTAL RIPORTÁLT KIMENETI MUTATÓK JELENTÓSÉGE POMPE-KÓRBAN
}

\author{
MOLNÁR Mária Judit, MOLNÁR Viktor, LÁSZLÓ Izabella, SZEGEDI Márta, \\ VÁRHEGYI Vera, GROSZ Zoltán
}

Semmelweis Egyetem, Genomikai Medicina és Ritka Betegségek Intézete, Budapest

Hungarian | https://doi.org/10.18071/isz.74.0105 | www.elitmed.hu

Háttér és cél - A modern, betegcentrikus egészségügyi ellátásban a beteg aktivitása, elvárásai, félelmei nagyobb szerepet kapnak a diagnózis gyors felállításának, objektíven mérhető terápiás válasz feltárásának alárendelt, orvoscentrikus információszerzéssel szemben. A krónikus betegségekben elengedhetetlen a betegek gyógyulási folyamatba történő bevonása. A Pompe-betegség egy ritka, örökletes, a lizoszomális tárolási rendellenességek közé tartozó kórkép, amelyben az a-glükozidáz enzimet kódoló gén funkcióvesztő mutációi következtében végtagöv- és axiális típusú izomgyengeség, légzési elégtelenség alakul ki. A betegség felismerésének jelentőségét kiemeli, hogy 15 éve elérhető a hiányzó enzimet a szervezetbe juttató, betegségmoduláló enzimterápia (ERT). Módszer - Jelen vizsgálatunkban a Pompe-kórban szenvedő betegek számára készítettünk beteg által riportált kimeneti mutatókat felmérő (PROM) kérdőívcsomagot, amelyben az általános életminőségi skálákat (EuroQoL, EQ-5D, SF-36), a mindennapi tevékenységekhez kapcsolt funkcionális képességeket, a mozgásteljesítményt és a vitalitást felmérő (R-PAct-Scale, Rotterdam és Bartel mozgáskorlátozottsági skála, Fatigue Severity Score) modulokat kombináltuk. Az adatokat három éven át gyújtöttük. A PROMs kérdőívek (patient reported outcome measures) jól kiegészítik az orvos által rögzített állapotfelmérést, és bizonyos aspektusokról (például a betegek objektív izomgyengeséget meghaladó mértékú fáradékonysága, stagnáló fizikai képességek és aktivitás mellett is romló társadalmi aktivitás, bizonyos doménekben igen jelentős individuális különbségek) csak a PROM-ok nyújtottak információt. A betegségteher pszichés hatásai is tükröződnek a PROM-okban.

\section{THE IMPORTANCE OF PATIENT REPORTED OUTCOME MEASURES IN POMPE DISEASE}

Molnár MJ, MD, PhD, DSc; Molnár V, MD; László I, MSc; Szegedi M, MD, PhD; Várhegyi V, MD; Grosz Z, MD Ideggyogy Sz $2021 ; 74(3-4): 105-115$.

Background and purpose - In recent decades it has become increasingly important to involve patients in their diagnostic and treatment process to improve treatment outcomes and optimize compliance. By their involvement, patients can become active participants in therapeutic developments and their observations can be utilized in determining the unmet needs and priorities in clinical research. This is especially true in rare diseases such as Pompe disease. Pompe disease is a genetically determined lysosomal storage disease featuring severe limb-girdle and axial muscle weakness accompanied with respiratory insufficiency, in which enzyme replacement therapy (ERT) now has been available for 15 years.

Methods - In our present study, patient reported outcome measures (PROMs) for individuals affected with Pompe disease were developed which included questionnaires assessing general quality of life (EuroQoL, EQ-5D, SF36), daily activities and motor performance (Fatigue Severity Score, R-PAct-Scale, Rotterdam and Bartel disability scale). Data were collected for three subsequent years.

The PROM questionnaires were a good complement to the physician-recorded condition assessment, and on certain aspects only PROMs provided information (e.g. fatigue in excess of patients' objective muscle weakness; deteriorating social activities despite stagnant physical abilities; significant individual differences in certain domains). The psychological effects of disease burden were also reflected in PROMs.

Results - In addition to medical examination and certain endpoints monitored by physicians, patient perspectives need to be taken into account when assessing the effectiveness of new, innovative treatments. With involvement of

Levelező szerző (correspondent): Dr. MOLNÁR Mária Judit, Semmelweis Egyetem, Genomikai Medicina és Ritka Betegségek Intézete; 1082 Budapest, Üllői út 78. Telefon: +3614591492, e-mail: molnar.mariajudit@med.semmelweis-univ.hu https://orcid.org/0000-0001-9350-1864

Érkezett: 2021. február 6. Elfogadva: 2021. február 28. 
Eredmény - Az úi, innovatív kezelések hatásosságának követésében az orvos által megfigyelt végpontok mellett szükséges a betegek nézópontjainak figyelembevétele is. A terápiás fejlesztések aktív szereplőivé váló betegek közremúködésével olyan információk nyerhetők, amelyek a reguláris orvosi vizitek alkalmával nem kerülnek felszínre, jóllehet alapvető fontosságúak a klinikai kutatások kérdéseinek és prioritásainak meghatározásában.

Következtetés - Minden forgalomban levő orphan gyógyszer vonatkozásában kívánatosnak tartjuk a betegek bevonását az általános és az adott kórképre jellemző állapotleírók többdimenziós gyújtésébe, azok időbeli változásának követését pedig javasoljuk felhasználni a kezelés hatásosságának monitorozása érdekében.

Kulcsszavak: beteg által riportált kimeneti mutatók (PROMs), valós életbeli adatok, terápiás hatásosság, Pompe-kór, ritka betegség, orphan gyógyszer patients, information can be obtained that might remain uncovered during regular medical visits, although it is essential in determining the directions and priorities of clinical research.

Conclusion - For all orphan medicines we emphasize to include patients in a compulsory manner to obtain general and disease-specific multidimensional outcome measures and use them as a quality indicator to monitor treatment effectiveness.

Keywords: patient reported outcome measures (PROMs), real world data, therapeutic effectiveness, Pompe disease, rare disease, orphan medicines
,A betegek megnyerése a gyógyulásban való részvételben a század szupergyógyszere lenne, amit ôrültség lenne nem kihasználni”, mondta Leonard Kish 2012-ben ${ }^{1}$. Ez különösen igaz ritka betegségekben, melyekben a technológia fejlődésének köszönhetően napjainkban folyamatosan nő az innovatív terápiák száma. Ezek hatásosságának mérése azonban sok esetben akadályba ütközik, kis esetszámokkal futnak a klinikai vizsgálatok, relatíve rövid idő alatt születnek meg a hatósági engedélyek, így sok információ csak a mindennapi alkalmazás kapcsán kerül napvilágra. Ezek követése azonban egyes országokban és betegségcsoportokban nagyon heterogén képet mutat.

A gyógyszerügyi hatóságok a randomizált kontrollált klinikai vizsgálatokban (RCT) általában olyan elsődleges végpontokat fogadnak el, melyek standardizáltak, objektívek, reprodukálhatók. Ezek alkalmazhatósága azonban sajnos gyakran, például a súlyosabb állapotban lévő betegek esetén, korlátokba ütközik. Neuromuscularis betegségekben a 6 perces járástávolság (6MWT) és a manuális izomerô teszt (manual muscle test, MMT) a leggyakrabban használt mutatók. Járóképességüket elvesztett betegek esetén a módosított felsô végtagi részfeladatokat vizsgáló RULM (revised upper limb modul) teszt használható, azonban azoknál a betegeknél, akik felső végtagi funkciói is súlyosan károsodottak, már a RULM teszt sem ad megfelelő információt, és ez a terápia hatékonyságának megítélését bizonytalanná teszi. A betegek által készített kimeneti és tapasztalati mutatók jelenthetnek segítséget ilyen esetekben. Napjainkban a legtöbb klinikai vizsgálatban már másodlagos végpontként szerepelnek ilyen mutatók, azonban ezeket a min- dennapi klinikai gyakorlatban még kevéssé használják. A segítségükkel megvalósítható hosszú távú adatgyújtés különösen jól kiegészítené a terápiás hatékonyság megítélését. Mit is jelentenek a fogalmak: PROM és PREM²?

\section{PROM: A beteg által riportált kimeneti mutatók (Patient reported outcome measures)}

A PROM a betegek által készített eredmények, kimeneti végpontok mérésére szolgáló eszköz. Ez standardizált, validált kérdőívekből áll, amelyeket maguk a betegek töltenek ki (szemben az orvosi vagy az ápolószemélyzet által jelentett leírásokkal). Célja az egészségi állapot felmérése, a fogyatékossággal és az egészséggel kapcsolatos életminőség megismerése. Ezek követése a beteg szemszögéből teszi lehetővé az alkalmazott terápia hatékonyságának értékelését. Összefoglalva, a PROM-ok a betegek általános vagy egészségi állapotukról alkotott saját véleményét mérik egy adott betegségben, így a klinikai hatékonyság és a biztonság mérésének eszközei.

A PROM-ok általános vagy betegségspecifikus kategóriákba sorolhatók. Az általános PROM kérdőívek az egészségügyi állapot aspektusainak széles skáláját fedik le, lehetővé téve az ellátás, az életminőség és a beavatkozások költséghatékonyságának átfogó értékelését. Emellett lehetőséget nyújt az érintett betegcsoport és az általános népesség, vagy éppen az egyes betegségcsoportok összehasonlítására is. A betegségspecifikus PROM-ok lehetővé teszik az aktuális állapot releváns aspektu- 
sainak vizsgálatát, és azok hatását mutatják a kimenetelre. További adaptációs lehetőséget jelentenek a gyermekekre, különböző korcsoportokra alkalmazható kérdőívcsomagok (pediatric quality of life inventory, PedsQL) is. A kérdőívek individualizálhatóak, ezáltal az egyén számára fontos elemek beemelésével, egyéni szempontok bevonásával a betegek tapasztalatai alapján jobban visszajelzik állapotukat.

\section{PREM: A beteg által riportált tapasztalati mutatók (Patient reported experience measures)}

A PREM-ek információt gyújtenek a betegek ellátás során szerzett tapasztalatairól. Ezek a betegellátás minőségét közvetett módon tükröző mutatók. A PREM-adatok leggyakrabban kérdőívek formájában készülnek. A PROM-adatokkal ellentétben a PREM-ek nem az ellátás kimenetelét kutatják, hanem az ellátás folyamata során a beteg által tapasztalt tényező́k hatását vizsgálják (az ellátó személyzet kommunikációja, az ellátás időszerúsége stb.). A legfőbb különbség a betegelégedettségi felmérésekhez képest az, hogy a PREM-adatok objektív betegélményekrôl számolnak be, kiiktatva a beteg által alkotott szubjektív vélemény közlését. A PREM-adatok relációs vagy funkcionális kategóriákba sorolhatók. A relációs PREM-ek a beteg ellátó személyzettel létesített interperszonális kapcsolatainak minőségét azonosítják a kezelés során, például érezte-e úgy, hogy meghallgatják ôt, odafigyelnek rá. A funkcionális PREM-ek viszont az előző kategóriával ellentétben inkább objektívebb feltételrendszert vizsgálnak, mint például egyes erőforrások rendelkezésre állása az ellátás során.

\section{Miért fontos a PROM- és PREM-adatokat gyúfiteni?}

A PROM-okból és a PREM-ekből gyújtött információknak számos felhasználási lehetősége van, úgymint kutatás, minőségfejlesztési projektek, kontrolling és gazdasági értékelés. Az összegyújtött adatok segítenek a betegközpontú klinikai menedzsment fejlesztésében és fókuszálásában, de hasznos viszszajelzést nyújtanak az egészségügyi szolgáltatók számára is, ami lehetôvé teszi az összehasonlítást a klinikai ellátásban. A PROM-ok egy beavatkozás vagy terápia betegségre gyakorolt hatásába, míg a PREM-ek az ellátás minôségébe nyújtanak betekintést. A kettốt gyakran párhuzamosan használják, hogy bemutassák a betegek észrevételeit, észlelé- seit mind az ellátás folyamatáról, mind eredményéről, kimenetéről.

\section{Hogyan kell a PROM- és a PREM-adatokat gyúiteni?}

A kérdőívek adatait egy előre meghatározott időpontban kell összegyújteni a vizsgált esemény vagy betegség vonatkozásában. A kérdőív kitöltésének optimális időzítése betegségenként és eljárásonként változik. A céladatok függetlenek, ezért a kérdőíveket az egészségügyi szakemberektől függetlenül kell kitölteni, szükség esetén egy barát vagy rokon segítségével. A PROM-okat és a PREM-eket e-mailben, weboldalak felhasználása segítségével online, vagy papíralapú kérdőívek segítségével tölthetik ki a betegek.

\section{A PROM- és a valós életbeli adatok jelentősége a gyógyszerfejlesztésben}

Az orvosi szektorban növekszik az érdeklődés a valós életbeli (real world) evidenciák iránt, ilyenek a PROM-adatok is. A gyógyszerügyi hatóságok (amerikai Élelmiszer- és Gyógyszer-felügyelet /FDA, Európai Gyógyszerügynökség/EMA) feladata, hogy a terápiás fejlesztéseket és innovációkat a lehető leghamarabb elérhetővé tegyék a nyilvánosság számára, a biztonságossági szempontok figyelemmel kísérése mellett. A hatóságok feladata ellátni az egyes új gyógyszerek forgalomba hozatal utáni felügyeletét az alkalmazás káros hatásainak és biztonságosságának figyelemmel kísérése érdekében. A gyógyszerfejlesztés során elkerülhetetlenné vált a real world adatok gyújtése. A randomizált, kontrollált klinikai vizsgálatok nem természetes, kontrollált környezetben igazolják a hatást. A real world evidenciák (RWE) viszont populációs szinten mutatják meg az adott beavatkozás hatékonyságát. Az FDA szerint a real world evidenciák a tipikus klinikai kutatási körülményeken kívül esô, több forrásból származó egészségügyi információk összessége, ideértve az elektronikus orvosi nyilvántartásokat, valamint a személyes digitális eszközök és egészségügyi alkalmazások által gyújtött adatokat és a beteg szubjektív megfigyeléseit ${ }^{3}$. Az RWE nem értékelhetô teljes mértékben a randomizált, kontrollált vizsgálatokkal (RCT) kapcsolatos limitációk tudomásulvétele nélkül. Az RCT-k szigorúan ellenőrzött körülmények között kezelt, „,szúrt” populációkat vizsgálnak, ezzel szemben az RWEadatok heterogén populációból származnak. Az RCT-k felbecsülhetetlen értékúek a javasolt beavat- 


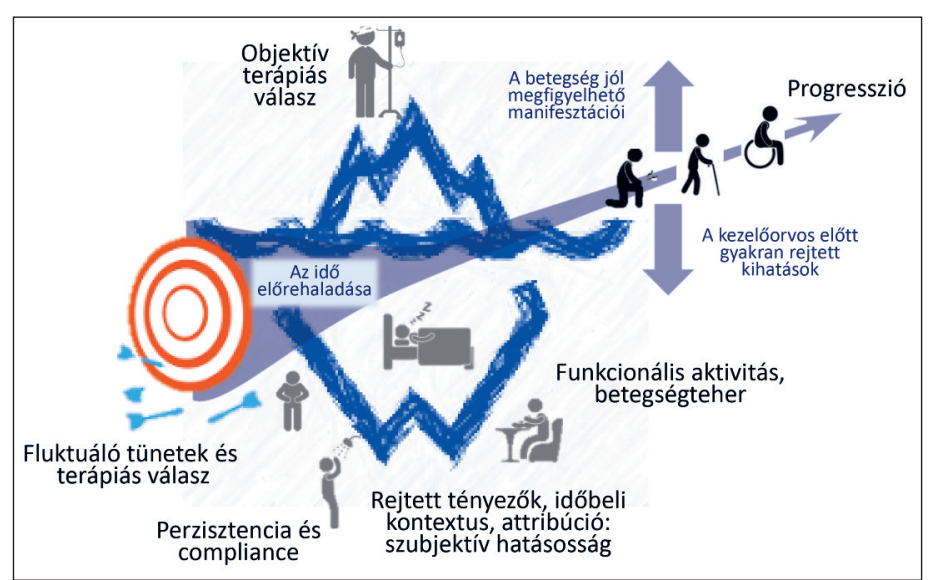

1. ábra. A krónikus, ritka betegségben szenvedö egyén követése során felmerülö szempontok és kérdések: Mit mérjünk? Milyen gyakran? Hogyan? Mikor avatkozzunk be?

kozás hatékonyságának igazolásában, de mennyire jó egy terápia a klinikai valóságban, ahol azt sokféle betegcsoportban alkalmazzák? Az RCT-adatok és az RWE adatainak összefonódása elősegítheti a terápiás modalitás valódi hatékonyságának és biztonságosságának meghatározását. Az ilyen hibrid hatékonysági vizsgálatok segíthetnek a való élettel való szorosabb összefüggés kialakításában egy klinikai fejlesztési program során.

Az FDA és az EMA szorgalmazzák a real world adatok beépítését a terápiás/orvostechnikai eszközök kutatásába, ami erősíti a tanulási visszacsatolási ciklusokat, függetlenül a tapasztalt nehézségektôl $1^{4-6}$.

Érdekes az a szerep, amelyet a beteg által készített kimeneti mutatók (PROM) játszhatnak az RWD létrehozásában, amelyből az RWE származhat. A PROM-ok tehát olyan eszközök, amelyekkel a betegség vagy a terápia hatása az egyéni tünetekre, az életminóségre vagy az egészségi állapotra közvetlenül a beteg szemszögéből értékelhetô. Ezek az életminőség mérésének arany standardjai (HRQoL), és egyre inkább beépülnek a randomizált klinikai vizsgálatokba. Az FDA és az EMA által jóváhagyott onkológiai gyógyszerek 70,3\%-ának volt PROMalapú végpontja is 2012 és 2016 között, amelyek hiányában a gyógyszerek az általános értelmezés szempontjából nem lennének teljes értékünek tekinthetôek ${ }^{7}$. Így, ha a gyógyszeripari és orvostechnikai eszközökkel foglalkozó vállalatok megalapozottan alátámasztott eredményeket kívánnak elérni, amelyek tükrözik a termék hatékonyságát a mindennapi klinikai használat során, a PROM-ok beépítése potenciális lehetôség ennek elérésére.

A PROM-ból nyert adatok eleget tesznek a real world adatok és a real world evidenciák kritériu- mainak. Ezek standardizált kérdőívekből származó strukturált adatok, amelyek könnyen értelmezhetôk, homogének és összehasonlító feldolgozásra adnak lehetőséget. Ezek a jellemzők előrevetítik a betegregiszterekben való használhatóságukat, ezáltal elősegítve az RWE fejlesztését és széles körú alkalmazását a terápiás és orvostechnikai eszközök fejlesztésében és értékelésében ${ }^{8}$.

\section{A PROM jelentősége a Pompe-kórban}

A Pompe-kórban 2006 óta áll rendelkezésünkre enzimpótló kezelés (ERT), az elsô magyar beteget 2006-ban kezdtük kezelni. Azóta 15 év telt el, és nagyon sok tapasztalatot szereztek kezelőorvosaink és kezelt betegeink egyaránt. A terápia hatásosságának mérését a finanszírozási protokoll által megkövetelt módon, félévente, strukturált adatbázisban szolgáltatott mutatók (laboreredmények, izomerőt és légzésfunkciót mérő tesztek) szolgálják. Ezek azonban minden alkalommal egy adott napon mért keresztmetszeti mutatók, melyeket befolyásolhatnak az adott nap egyéb történései. Egy krónikus betegségben szenvedő egyén betegségmenedzsmentje során számos paraméter követendő, az objektív végpontok mellett az egyes panaszok időbelisége, fluktuációja, az életminőségre és a napi aktivitásra kifejtett hatásokkal együtt (1. ábra). A PROM-ok képesek felmérni az adott terápia olyan hatásait is, amelyek hagyományos orvosi vizsgálattal nem minden esetben figyelhetőek meg (1. táblázat), és betekintést nyújthatnak a beteg felfogásába azzal kapcsolatosan, hogy a betegség vagy a kezelés hogyan befolyásolja az egészséggel kapcsolatos életminőséget (HRQoL, Health Related Quality of Life). A krónikus betegségek, mint amilyen a Pompe-kór is, nagy hatással vannak a HRQoL-re úgy a fizikai, mint a pszichológiai és szociális funkciók területén. Az olyan tünetek, mint a fáradtság, fájdalom, izomgyengeség és atrophia interferálnak a mindennapi élet tevékenységeivel (ADL, Active Daily Living), ami átfogó hatást eredményezhet a HRQoL-re. Egy korábbi tanulmányban a Pompekórban szenvedó betegek fájdalommal kapcsolatos panaszairól azt írták le, hogy a fájdalom összefügg a HRQoL csökkenésével, a mindennapi életben való csökkent részvétellel, valamint a depresszió és szorongás magasabb előfordulásával ${ }^{9}$.

A modern orvosi technológia annak ellenére, hogy képes mérni egy beteg fizikai, fiziológiai és biokémiai adatait, mégsem képes minden, a kezeléssel vagy a betegséggel kapcsolatos adat meghatározására. A HRQoL javítása, a betegség terheinek csökkentése nagy szerepet játszik a betegek elége- 
1. táblázat. Az orvosi döntéseket támogató információk, melyek kizárólag csak a betegtól nyerhetók

\begin{tabular}{|c|c|}
\hline $\begin{array}{l}\text { Szubjektív, nem } \\
\text { megfigyelhető" } \\
\text { problémák }\end{array}$ & $\begin{array}{l}\text { a probléma természetéből fakadóan nehezen megítélhető (például fejfájás, szorongás, } \\
\text { fáradékonyság) } \\
\text { nem a vizsgáló jelenlétében jelentkező tünetek (például alvászavar, epizodikusan jelent- } \\
\text { kező, nem triggerelhető jelenségek) } \\
\text { legfeljebb indirekt jelek alapján észlelhető panaszok (például nyelési diszkomfort) }\end{array}$ \\
\hline $\begin{array}{l}\text { Egy adott probléma } \\
\text { intenzitása és időbeli } \\
\text { alakulása }\end{array}$ & $\begin{array}{l}\text { megfeleltetés rangsorolt kategóriáknak vagy Vizuális Analóg Skála leíró és numerikus } \\
\text { horgonyokkal (például } 0 \text { „nincs fáidalom” és } 100 \text { „rendkívüli fáidalom” között) } \\
\text { időszakosan jelentkező panaszok } \\
\text { gyakoriság egy adott időszak alatt (például napi vagy havi rendszerességű?) } \\
\text { kontextus, egyedi értelmezés (például akkor egy sérülés miatt fáił) }\end{array}$ \\
\hline $\begin{array}{l}\text { Releváns, problémához } \\
\text { kapcsolódó, egymásra } \\
\text { épülő mutatók átfogó és } \\
\text { betegségspecifikus fel- } \\
\text { mérése }\end{array}$ & $\begin{array}{l}\text { funkcionális képességek } \\
\text { fizikai teljesítmény } \\
\text { korlátozottság a mindennapi tevékenységek során } \\
\text { egészséggel kapcsolatos életminőség } \\
\text { (érzelmi és társadalmi) jóllét }\end{array}$ \\
\hline $\begin{array}{l}\text { A probléma megoldására } \\
\text { tett próbálkozások sike- } \\
\text { rességének mérése }\end{array}$ & $\begin{array}{l}\text { a páciens narrációja a betegség alakulásával, illetve a kapott kezeléssel kapcsolatban } \\
\text { változás több dimenzióban és időben történó követése }\end{array}$ \\
\hline
\end{tabular}

dettségében, ezt azonban egy klinikai vizsgálat során a fiziológiai paraméterek mérésével nem lehet rögzíteni.

Harfouche és munkatársai egy PROMIS néven fejlesztett kérdőívcsoportot alkalmaztak a Pompekór klinikailag releváns jeleinek (légzőszervi és motoros tünetek) felmérésére. Az ebben a vizsgálatban szereplő öt PROM-értékelés PROMIS kérdőívekkel történt, amelyek a Pompe-betegséggel összefüggố ismert szempontokat (fájdalom, felső végtagi funkció, fáradtság, fizikai funkció és dyspnoe) mérték fel ${ }^{10}$. Egy másik tanulmányban kimutatták, hogy a fáradtság nagyon gyakori mind az enyhe, mind a súlyos mértékben érintett felnőtt Pompe-betegek körében, aminek felméréséhez a Fatigue Severity Scale-t (fáradtság súlyosságának mértékét felmérô skála) alkalmazták ${ }^{11}$.

\section{Betegek és módszerek}

Tanulmányunkban összesen 22 Pompe-beteget kértünk meg a PROM-ok kitöltésére. A kérdőívek kitöltését egy orvos-beteg találkozó előzte meg, amelyen a betegek részletes felvilágosítást kaptak egy ismeretterjesztô előadás formájában arról, hogy miért fontos a véleményük a betegség kezelésének megítélésben. A kérdőívet a Semmelweis Egyetem Genomikai Medicina és Ritka Betegségek Intézetének (SE GRI) honlapján online lehet elérni (https://semmelweis.hu/genomikai-medicina/betegeknek/), de kérésre papíralapú kérdőívet is biztosítottunk betegeink számára.
A kérdőívek a következő fő szempontok szerint kerültek összeállításra: 1. általános életminőségi skálák, 2. vitalitás, mozgásteljesítmény, mindennapi tevékenységek felmérését célzó kérdőívek, 3. a fizikai állapot változását és az ERT hatásosságát felmérô kérdőívek.

Az általános életminőségi skálák közül az EuroQoL skálát, az EQ-5D egészségi állapot kérdőívet és az SF-36 kérdőívet töltötték ki a betegek. A betegek mindennapi aktivitását, mozgásteljesítményét a fáradékonysági pontszámmal és Vizuális Analóg Skálával (Fatigue Severity Score), a Pompe-specifikus aktivitási skálával ${ }^{12}$ (Rasch-built Pompe-specific Activity, R-PAct scale), és a Rotterdam mozgáskorlátozottsági skálával mértük. A PROM-okat évente legalább egy alkalommal vettük fel a követés három éve során.

A leíró statisztikai változókat az előfordulási gyakoriság százalékos arányában adtuk meg. A folyamatos változókat az átlagérték és a standard deviáció (egyes esetekben, ahol ezt fel is tüntettük: minimum, maximum, illetve 95\%-os megbízhatósági tartomány) értékeivel jellemeztük. Több esetben előfordult, hogy egyes kérdőívek kitöltése nem volt teljes, a hiányzó adatokat utólag nem pótoltuk, és az adott kérdőívet mint elemet kizártuk a kérdőívcsomag további összegzéséből. Az idő előrehaladtával történő változások követése érdekében végzett összehasonlításoknál csak azokat a betegeket vontuk be az értékelésbe, akik esetében legalább két alkalommal, legalább az elsô és a harmadik évben rendelkezésre állt a kérdéses adat. 


\section{Mit javasolna a vizsgáló számára: milyen gyakran mérjük az aktuális állapotát?}

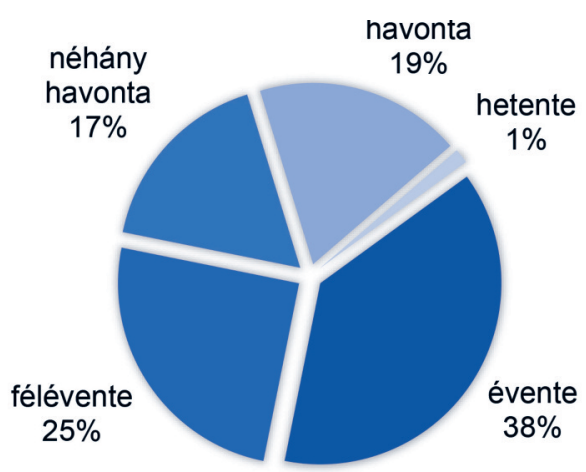

2. ábra. A betegek véleménye a PROM-okfelvételének gyakoriságáról

A páciensek megítélése szerint a hasznos felmérési gyakoriság nagyon heterogén képet ad. Időben visszatekintve a változások inkább csak nagyobb időtávban érzékelhetőek, többségében egyetértenek a kérdőív által vizsgált mutatók rendszeres, félévente-évente történő felvételével. Harmaduk véleménye szerint akkor is szükséges lenne a felmérés, ha érzékelhető változást tapasztalnak a betegségnek tulajdonítható állapotukban.

\section{Eredmények}

Az első alkalommal, az ismeretterjesztő előadást követôen 22 betegből 20 töltötte ki a kérdőívet online formában. A betegek átlagéletkora 43,2 + 19,6 év, a férfiak és a nók megoszlása $35-65 \%$ volt. A követett betegek többsége (85\%) késői kezdetû Pompe-kórban szenvedett, a betegség stádiuma és az $\alpha$-glükozidáz enzimpótló (ERT-) kezelés ideje különböző volt. A betegség kezdete és az elsô kérdőív kitöltése között átlagosan 13,14 $\pm 8,23$ év (minimum 1,38 - maximum 27,77) telt el. Valamennyi beteg részesült ERT-kezelésben. A kohorsz-

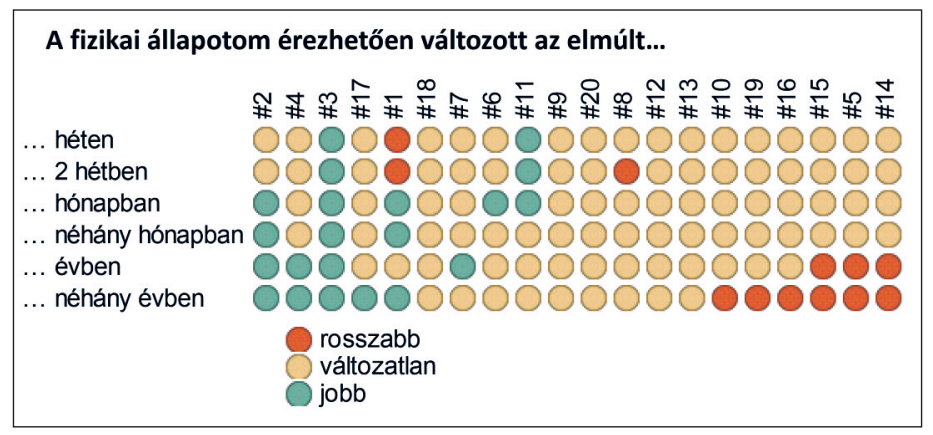

3. ábra. A fizikai állapot szubjektív (!) idôbeli változásának mintázatai az egyes követett betegeknél

Többféle típus különíthető el, jóllehet a betegség jellemzően lassú progressziójának követése éves vagy akár több éves visszatekintéssel lehet megbízható, nem is említve az életkori sajátosságokat és a társbetegségek szerepét. ban szereplő egyének 25\%-ánál a kezelés időtartama meghaladta az 5 évet.

Előzetes felmérés alapján (2. ábra) egyeztetve, a betegek félévente-évente vállalták a kérdőív kitöltését. A kérdésre, miszerint „Mit javasolna a vizsgáló számára: milyen gyakran mérjük fel az aktuális állapotát?", sokan a rendszeres felmérés mellett szükségesnek tartják a kérdőív kitöltését, ha állapotukban érzékelhetô változás következik be. Évente a közösségi médián keresztül is emlékeztettük őket a kérdőívek kitöltésére, de azt nem tettük kötelezôvé. A személyes kapcsolat az általunk gondozott betegekkel szorosnak volt mondható, hiszen az ERT-kezelés miatt a betegek 2 hetente több órás infúziós kezelésben vettek részt intézetünkben. A betegek motivációja a felmért időszakban változónak bizonyult, néhányan rendszeresen, minden megbeszélt alkalommal kitöltötték a kérdőíveket, míg másokat többször kellett emlékeztetni erre. A 20 betegből 12 esetben sikerült mindkét, 3 év különbséggel kitúzött megfigyelési ablakban válaszokat kapnunk (amiben az is szerepet játszik, hogy további öt fő az elsó időablakban még nem került a látókörünkbe). A szubjektív, betegek által érzékelhető mértékú változásról a többség inkább éves-többéves távlatban tud beszámolni. 5/20 fó jobbnak ítélte meg az állapotát, mint néhány évvel ezelőtt, 9/20 fő állapotának stagnálásáról, 6/20 fő romlásról számolt be az elsố felmérési időszakban (3. ábra).

A PROM-ok között szerepelt a késôi indulású Pompe-kórban specifikusan alkalmazható funkcionális skála (R-Pact) is. A résztvevốk az „Ön képes-e az alábbi tevékenységek elvégzésére?" kérdésre az „egyáltalán nem”-tôl a „,soha nem okozott gondot"-ig terjedô 5 fokozatú skálán adhattak választ; a válaszokat a felmérési időszakban riportált legjobb eredmények figyelembevételével összegeztük. A funkcionális R-Pact skála kérdéseit és a kapott válaszok eloszlását a 4. ábrán mutatjuk be. A kérdő́iveket kitöltők az egyes funkcionális képességeiket tekintve széles skálán mozognak, ami nem meglepő: amellett, hogy ez az R-Pact kérdéssor fejlesztóinek is célja volt ${ }^{12}$, a betegség különböző stádiumában vannak, a kezelésre különböző módon reagálhatnak, sőt egy-egy képesség jelentőségét egyénileg különbözőképpen értékelhetik. Egy beteg adott olyan választ, hogy minden funkciót tökéletesen el tud látni (\#9 sorszámú beteg), míg egy beteg az összes kérdést figyelembe véve csak az elérhető pontszámok 18\%-át (\#11) elérô állapotról számolt be (5. ábra). A betegek 98\%-a a könnyú, főként felső végtagi, distalisan megtartott funkciót igénylő feladatokat - mint például könnyú tárgyak felvétele az asztalról, vagy az önálló evés - gond nélkül teljesíteni tudta. Mindössze három beteg volt a kohorszunkban, akik 


\begin{tabular}{|c|c|c|c|c|c|c|c|c|c|c|c|c|c|c|c|c|c|c|c|c|c|}
\hline \multirow{3}{*}{ ztalrc } & 咮 & \# & 号 & $\stackrel{m}{\#}$ & \# & $\#$ & $\frac{N}{\#}$ & $\underset{\#}{\infty}$ & \# & 㖼 & $\frac{12}{\#}$ & $\#$ & \# & 蛋 & $\underset{\#}{\#}$ & 음 & $\frac{0}{\#}$ & $\underset{\#}{\stackrel{N}{*}}$ & 年 & 苂 & \\
\hline & ㅇํㅇ & ஓ̊ & $\begin{array}{l}\text { 今े } \\
\text { \% }\end{array}$ & 今̊ & ஓ゚ & ஓ̊ & $\begin{array}{l}\text { ○े } \\
\text { டे }\end{array}$ & ‡̊ & ஓ̊ & 㐫 & \$̊ & 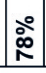 & 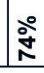 & ஓे & $\frac{\pi}{\frac{\pi}{2}}$ & ণั่ & $\frac{2}{0}$ & సั่ & 商 & 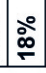 & \\
\hline & 100 & 100 & 100 & 100 & 100 & 100 & 100 & 100 & 100 & 100 & 100 & 100 & 100 & 100 & 100 & 100 & 50 & 100 & 100 & 100 & \#\#\# \\
\hline \multirow{3}{*}{$\begin{array}{r}\text { Enni (nyelni, rágni) } \\
\text { Egy tubus csavaros zárókupakos fogkrémet kinyitni } \\
\text { Telefont vagy számítógépet használni }\end{array}$} & 100 & 100 & 100 & 100 & 100 & 100 & 100 & 100 & \begin{tabular}{|l|l|} 
\\
\end{tabular} & \begin{tabular}{|l|l}
0 \\
\end{tabular} & 100 & 100 & 100 & \begin{tabular}{|l|l} 
& 100 \\
\end{tabular} & 100 & 100 & 75 & 100 & 100 & 75 & \#\#\# \\
\hline & 100 & 100 & 100 & 100 & 100 & 100 & 100 & 100 & \begin{tabular}{|l|l|} 
& 100 \\
\end{tabular} & 100 & 100 & 100 & \begin{tabular}{|l|l} 
& 100 \\
\end{tabular} & \begin{tabular}{|l|l|} 
& 100 \\
\end{tabular} & 100 & 100 & 50 & 100 & 100 & 75 & \#\#\# \\
\hline & 100 & 100 & 100 & 100 & 100 & 100 & 100 & 100 & 100 & 100 & 100 & 100 & 100 & 100 & 100 & 100 & 75 & 100 & 100 & 50 & \#\#\# \\
\hline \multirow{3}{*}{$\begin{array}{r}\text { Behúzni egy cipzárt } \\
\text { Fogat mosni } \\
\text { İ́ni }\end{array}$} & 100 & 100 & 100 & 100 & 100 & 100 & 100 & 100 & \begin{tabular}{|l|l} 
& 100 \\
\end{tabular} & 100 & 100 & 100 & \begin{tabular}{|l|l} 
& 100 \\
\end{tabular} & \begin{tabular}{|l|l} 
\\
\end{tabular} & 100 & 100 & 50 & 100 & 100 & 50 & \#\#\# \\
\hline & 100 & 100 & 100 & 100 & 100 & 100 & 100 & 100 & 100 & 100 & 100 & 100 & 100 & 100 & 100 & 100 & 75 & 100 & 100 & 25 & \#\# \\
\hline & 100 & 100 & 100 & 100 & 100 & 100 & 100 & 100 & 100 & 100 & 100 & 100 & 100 & 100 & 100 & 75 & 50 & 100 & 100 & 50 & \#\#\# \\
\hline \multirow{2}{*}{$\begin{array}{l}\text { Begombolni az ingét } \\
\text { zos vagy zacskós italt }\end{array}$} & 100 & 100 & 100 & 100 & 100 & 100 & 100 & 100 & 100 & 100 & 100 & 100 & 100 & 100 & 100 & 100 & 50 & 100 & 100 & 25 & \#\# \\
\hline & 100 & 100 & 100 & 100 & 100 & \begin{tabular}{|l|l} 
\\
\end{tabular} & 100 & 100 & 100 & 100 & 100 & 100 & 100 & \begin{tabular}{|l|l|}
100 \\
\end{tabular} & 75 & 100 & 50 & 100 & 100 & 50 & \#\#\# \\
\hline \multirow{2}{*}{$\begin{array}{l}\text { Lezuhanyozni } \\
\text { Nadrágot felhúzni (cipzározás és gombolás nélkül) }\end{array}$} & 100 & 100 & 100 & 100 & 100 & 100 & 100 & 100 & 100 & \begin{tabular}{|l|l}
0 & 100 \\
\end{tabular} & 100 & 100 & 100 & \begin{tabular}{|l|l}
100 \\
\end{tabular} & 100 & 100 & 75 & 100 & 75 & 0 & \#\#\# \\
\hline & 100 & 100 & 100 & 100 & 100 & 100 & 100 & 100 & 100 & 100 & 100 & 100 & 100 & 100 & 100 & 100 & 75 & 100 & 50 & 25 & \#\#\# \\
\hline \multirow{2}{*}{$\begin{array}{r}\text { Megfésülködni } \\
\text { Megközelítöleg } 10 \text { métert sétálni }\end{array}$} & 100 & 100 & 100 & 100 & 100 & 100 & 100 & 100 & 100 & \begin{tabular}{|l|l|}
0 \\
\end{tabular} & 100 & 100 & 100 & \begin{tabular}{|l|l|} 
& 100 \\
\end{tabular} & 100 & 100 & 75 & 100 & 75 & 0 & \#\#\# \\
\hline & 100 & 100 & 100 & 100 & 100 & 100 & 100 & 100 & 100 & 100 & 75 & 100 & 100 & 100 & 100 & 100 & 50 & 100 & 100 & 0 & \#\#\# \\
\hline & 100 & 100 & 100 & 100 & 100 & 100 & 100 & 100 & \begin{tabular}{|l|l}
100 \\
\end{tabular} & \begin{tabular}{|l|l|}
0 & 100 \\
\end{tabular} & 100 & 100 & 100 & 100 & 100 & 50 & 75 & 100 & 75 & 0 & \#\#\# \\
\hline Pulóvert vagy pólót felvenni & 100 & 100 & 100 & 100 & 100 & 100 & 100 & 100 & 100 & 100 & 100 & 100 & 100 & 100 & 100 & 100 & 75 & 75 & 0 & 25 & \#\# \\
\hline Állni & 100 & 100 & 100 & 100 & 100 & 100 & 100 & 100 & 100 & 100 & 75 & 100 & 75 & 100 & 75 & 100 & 50 & 100 & 100 & 0 & \#\#\# \\
\hline \multirow{2}{*}{$\begin{array}{l}\text { zználni a mosdót } \\
\text { Ételt készíteni }\end{array}$} & 100 & 100 & 100 & 100 & 100 & 100 & 100 & 100 & 100 & 100 & 100 & 100 & 100 & 100 & 100 & 100 & 75 & 100 & 0 & 0 & \#\# \\
\hline & 100 & 100 & 100 & 100 & 100 & 100 & 100 & 100 & 100 & 100 & 100 & 100 & 75 & 100 & 100 & 100 & 75 & 100 & 25 & 0 & \#\#\# \\
\hline Megközelítöleg 100 métert sétálni & 100 & 100 & 100 & 100 & 100 & 100 & 100 & 100 & 100 & 100 & 75 & 100 & 100 & 75 & 100 & 75 & 50 & 75 & 75 & 0 & \#\# \\
\hline \multirow{2}{*}{$\begin{array}{r}\text { Arcot mosni mosdónál } \\
\text { Elérni és megfogni egy feje felett elhelyezkedö tárgyat }\end{array}$} & 100 & 100 & 100 & 100 & 100 & 100 & 100 & 75 & 100 & 100 & 100 & 100 & 100 & 100 & 100 & 100 & 75 & 75 & 0 & 0 & \#\# \\
\hline & 100 & 100 & 100 & 100 & 100 & 100 & 100 & 100 & 100 & 100 & 75 & 100 & 75 & 100 & 50 & 75 & 50 & 75 & 25 & 75 & \#\# \\
\hline Munkahelyi feladatainak vagy tanulmányainak eleget tenni & 100 & 100 & 100 & 100 & 100 & 100 & 100 & 100 & 100 & 100 & 75 & 100 & 50 & 100 & 75 & 100 & 75 & 75 & 0 & 0 & \#\#\# \\
\hline Hobbiját kivitelezni & 100 & 100 & 100 & 100 & 100 & 100 & 100 & 100 & 100 & 100 & 75 & 100 & 100 & 75 & 75 & 25 & 75 & 50 & 75 & 0 & \#\#\# \\
\hline Családtagokat és barátokat meglátogatni & 100 & 100 & 100 & 100 & 100 & 100 & 100 & 100 & 100 & 100 & 100 & 100 & 50 & 75 & 75 & 25 & 75 & 25 & 25 & 50 & \#\#\# \\
\hline Élelmiszert vásárolni & 100 & 100 & 100 & 100 & 100 & 100 & 100 & 100 & 100 & 100 & 75 & 100 & 75 & 100 & 75 & 25 & 75 & 0 & 0 & 25 & \#\#\# \\
\hline Ágyban megfordulni & 100 & 100 & 100 & 100 & 100 & 100 & 100 & 100 & 100 & 50 & 75 & 75 & 75 & 50 & 50 & 75 & 50 & 25 & 25 & 100 & \#\#\# \\
\hline Több mint 1 km-t sétálni & 100 & 100 & 75 & 100 & 100 & 100 & 100 & 100 & 100 & 100 & 100 & 100 & 75 & 50 & 50 & 25 & 50 & 50 & 0 & 0 & \#\#\# \\
\hline Küszöböt átlépni vagy útjában álló akadályt megkerülni & 100 & 100 & 100 & 100 & 100 & 100 & 100 & 100 & 100 & 50 & 50 & 75 & 75 & 100 & 75 & 50 & 50 & 25 & 0 & 0 & \#\#\# \\
\hline Egyenesen felülni segitség nélkül & 100 & 100 & 100 & 25 & 100 & 100 & 100 & 100 & 100 & 75 & 75 & 75 & 100 & 50 & 50 & 25 & 50 & 0 & 25 & 75 & \#\#\# \\
\hline Könnyen eljutni a boltba és a postára & 100 & 100 & 100 & 100 & 100 & 75 & 100 & 100 & 100 & 100 & 50 & 75 & 50 & 75 & 75 & 25 & 75 & 0 & 0 & 25 & \#\#\# \\
\hline Hanyatt fekvésböl felállni & 100 & 100 & 100 & 100 & 100 & 100 & 100 & 100 & 100 & 100 & 75 & 75 & 25 & 50 & 50 & 25 & 50 & 25 & 25 & 0 & \#\#\# \\
\hline Autóba be- és kiszállni & 100 & 100 & 100 & 100 & 100 & 100 & 100 & 100 & 100 & 50 & 75 & 75 & 75 & 50 & 50 & 50 & 50 & 25 & 0 & 0 & \#\#\# \\
\hline Egyenetlen talajon sétálni ( $\mathrm{pl}$. macskaköves utcán)? & 100 & 100 & 100 & 100 & 100 & 100 & 75 & 100 & 100 & 100 & 100 & 50 & 75 & 25 & 50 & 50 & 50 & 25 & 0 & 0 & \#\#\# \\
\hline Teljesen felmenni és lemenni egy lépcsőn (kb. 14 lépcsőfokot) & 100 & 100 & 100 & 100 & 100 & 100 & 100 & 100 & 100 & 75 & 50 & 25 & 75 & 25 & 75 & 75 & 50 & 25 & 0 & 0 & \#\# \\
\hline Autót vezetni & 100 & 100 & 100 & 100 & 100 & 0 & 100 & 100 & 100 & 100 & 100 & 100 & 25 & 75 & 75 & 0 & 100 & 0 & 0 & 0 & \#\#\# \\
\hline Félig fel- és lemenni egy lépcsőn (kb. 7 lépcsőfokot) & 100 & 100 & 100 & 100 & 100 & 100 & 100 & 100 & 100 & 50 & 75 & 25 & 75 & 25 & 100 & 25 & 50 & 25 & 0 & 0 & \#\#\# \\
\hline Házimunkát elvégezni (porszivózás, felmosás, vasalás, ablaktisztítás) & 100 & 100 & 100 & 100 & 100 & 100 & 50 & 75 & 50 & 75 & 50 & 50 & 75 & 75 & 50 & 50 & 75 & 50 & 0 & 0 & \#\# \\
\hline Ülő helyzetböl felállni & 100 & 100 & 100 & 100 & 100 & 100 & 100 & 100 & 100 & 25 & 50 & 25 & 75 & 75 & 50 & 25 & 50 & 25 & 0 & 0 & \#\#\# \\
\hline Fel- és leszállni egy bicikliröl & 100 & 100 & 100 & 100 & 100 & 100 & 100 & 100 & 75 & 50 & 75 & 75 & 25 & 50 & 50 & 25 & 50 & 0 & 0 & 0 & \#\# \\
\hline Felhajtón vagy emelkedőn sétálni & 100 & 100 & 100 & 100 & 100 & 100 & 100 & 75 & 50 & 50 & 75 & 75 & 75 & 25 & 25 & 50 & 50 & 25 & 0 & 0 & \#\#\# \\
\hline Sportolni & 100 & 100 & 100 & 100 & 50 & 100 & 100 & 75 & 75 & 100 & 75 & 75 & 25 & 50 & 25 & 25 & 75 & 25 & 0 & 0 & \#\#\# \\
\hline Tömegközlekedéssel utazni & 100 & 100 & 100 & 100 & 100 & 100 & 75 & 100 & 75 & 100 & 25 & 25 & 25 & 50 & 75 & 25 & 75 & 0 & 0 & 0 & \#\# \\
\hline Lehajolni egy földön fekvö tárgyért majd ismét felállni & 100 & 75 & 100 & 100 & 100 & 100 & 100 & 100 & 75 & 75 & 25 & 25 & 75 & 25 & 75 & 25 & 50 & 0 & 0 & 0 & \#\#\# \\
\hline Kerékpározni & 100 & 100 & 100 & 100 & 100 & 50 & 100 & 100 & 75 & 75 & 50 & 75 & 25 & 75 & 0 & 25 & 75 & 0 & 0 & 0 & \#\#\# \\
\hline Térdét behajlitani, majd újra felállni & 100 & 75 & 100 & 100 & 100 & 100 & 100 & 100 & 100 & 25 & 50 & 50 & 50 & 25 & 50 & 25 & 50 & 0 & 0 & 0 & \#\#\# \\
\hline Ház körüli és kerti teendőket ellátni & 100 & 100 & 100 & 100 & 100 & 100 & 75 & 50 & 25 & 75 & 50 & 25 & 25 & 75 & 25 & 50 & 75 & 25 & 25 & 0 & \#\#\# \\
\hline Sok lépcsöt megmászni & 100 & 100 & 100 & 75 & 100 & 100 & 100 & 75 & 25 & 50 & 75 & 25 & 25 & 25 & 25 & 75 & 50 & 25 & 0 & 0 & \#\#\# \\
\hline Gyorsan sétálni & 100 & 100 & 75 & 100 & 100 & 75 & 75 & 75 & 25 & 50 & 75 & 25 & 75 & 25 & 25 & 25 & 50 & 0 & 0 & 0 & \#\#\# \\
\hline Szaladni (pl. hogy elérjen egy vonatot) & 100 & 100 & 75 & 75 & 25 & 100 & 25 & 25 & 0 & 25 & 25 & 0 & 25 & 0 & 25 & 25 & 25 & 0 & 0 & 0 & \#\#\# \\
\hline
\end{tabular}

4. ábra. A késối indulású Pompe-kórban betegségspecifikusan alkalmazható funkcionális skála (R-pact) felvétele

A betegséggel eltérő mértékben érintett és a klinikai lefolyás különböző fázisaiban lévő követett betegek (oszlopokban, összpontszám szerint rendezve) és az egyes funkcionális képességek (sorokban) eloszlása. A résztvevők az „Ön képes-e az alábbi tevékenységek elvégzésére?” kérdésre az „,egyáltalán nem”-tốl a „,soha nem okozott gondot”-ig terjedő 5 fokozatú skálán adhattak választ; a válaszokat a felmérési időszakban riportált legjobb eredmények figyelembevételével összegeztük.

50\%-os vagy annál nagyobb funkcióvesztést jeleztek az adott kérdések vonatkozásában. Legnehezebb feladatként a futás képességét értékelték.

Azon esetekben, amelyekben rendelkezésre állt mindkét felmérési idôpontban kitöltött skála, lehetôség volt a funkcionalitás változásának megítélésére is. Figyelemre méltó a skála széles dinamikus tartománya: a legrosszabb állapotú, kerekesszéket használó betegünk, aki csak 18\%-osra értékelte funkcióit, egyes képességekben érzékelhető progresszióról számolt be. Hatékony áttekintést adhat, ha egy adott mértékú (például 25\%-os) változást mutató képesség pozitív és negatív irányú eltérését összegezzük (5. ábra). 


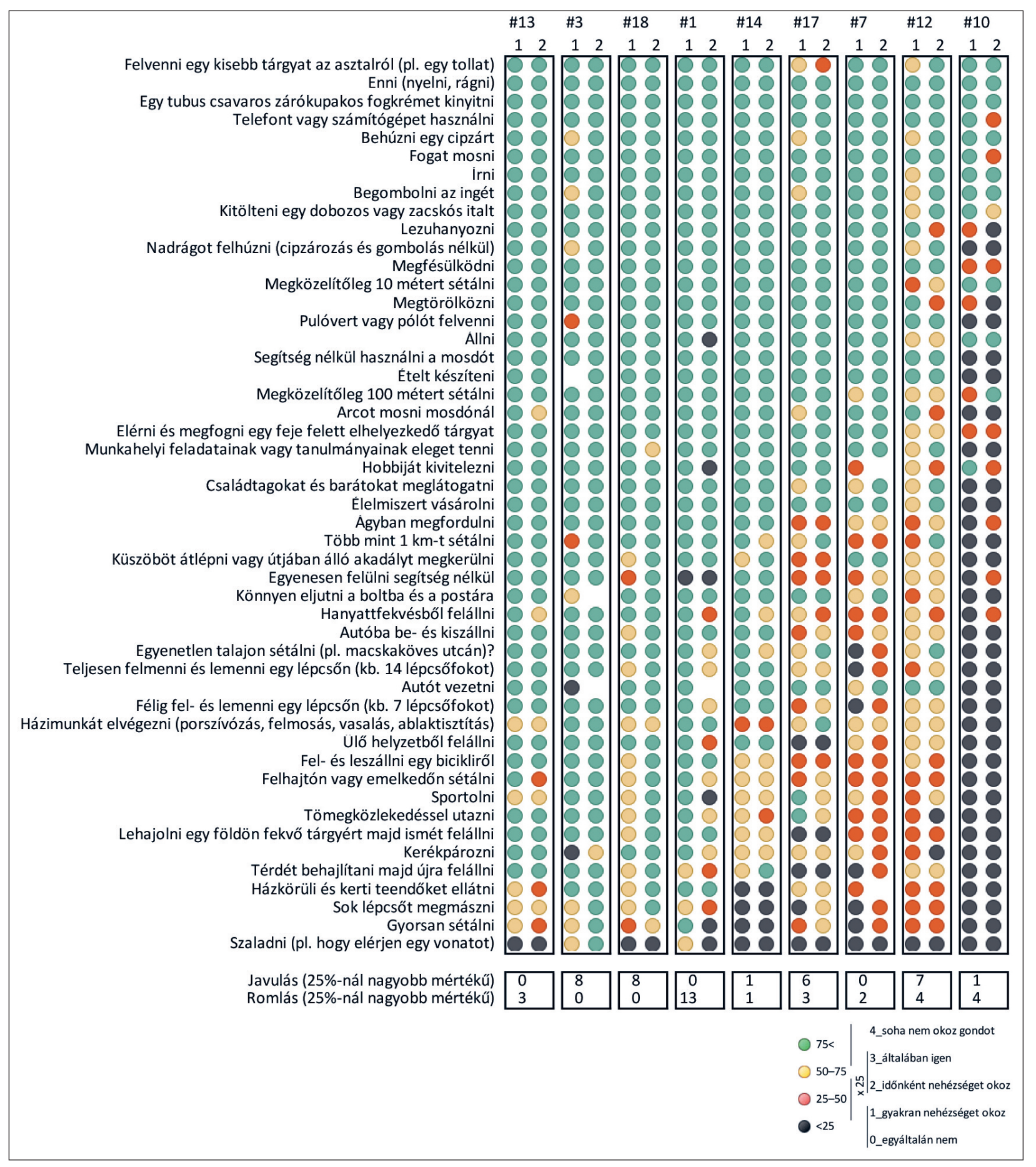

5. ábra. A késói indulású Pompe-kórban betegségspecifikusan alkalmazható funkcionális skála (R-pact) két idópontban történó felvétele 3 év különbséggel

A funkcionális képességek felvétele során kirajzolódó profil jellemző az egyénre, és a 3 év elteltével mutatkozó különbség egy-egy képességben mutatkozik meg. Reprezentatív esetek, amelyekben a legalább 25\%-os mértékú javulást vagy romlást mutató képességek számát összesítettük a két időpont között. Az ábra jelmagyarázata a 0-100\%-ra történő átfordítás logikáját demonstrálja.

A fáradékonysági skála meglepó eredményt hozott, ugyanis még abban az esetben is, ha a többi kérdőív alapján nem jeleztek betegségükben progressziót, ez a skála szinte az összes válaszadó- nál romlást mutatott a 2. kitöltés során (6. ábra). A fáradékonyság a betegek elmondása szerint fluktuált, és nem volt mindig összefüggésben az izomerővel. 


\section{Fáradékonyság VAS}

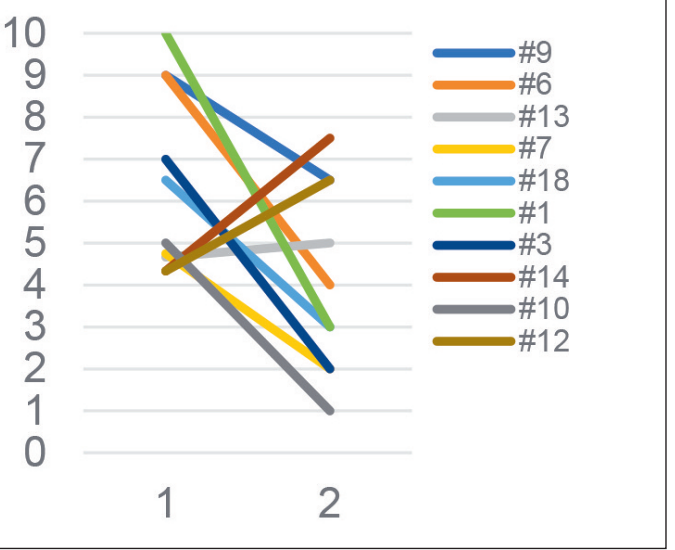

6. ábra. A résztvevók által riportált fáradékonysági pontszámok (VAS: Vizuális Analóg Skálán a 0: elképzelhetố legrosszabbtól a 10: tünetmentesig)

Az SF-36 kérdőív nyolc alskálával 36 kérdésbe tömörítve méri fel a betegek egészségi állapotukról alkotott véleményét. A kérdőív nyolc életminőségi kérdéscsoportot tartalmaz a fizikai aktivitás, a fizikai problémákból adódó szerepkorlátozottság, a testi fájdalom, az általános egészségérzet, a vitalitás, a társadalmi aktivitás, az érzelmi problémákból adódó szerepkorlátozottság és az általános mentális egészség témakörében. Az egyenes és fordított kérdések figyelembevételével az egyes alskálák pontszámait 0-tól 100-ig terjedő skálára konvertáltuk. Így minél magasabb a pontszám, annál kisebb a korlátozottság mértéke, illetve magasabb az egészséggel kapcsolatos életminőség, tehát 0 a legsúlyosabb állapotot, 100 az egészségeset jelzi. A 7. ábrán látható, hogy az SF-36 összesített átlagérték egyáltalán nem jelezte az életminőség romlását a 3 év alatt. Az egyes alskálák megvizsgálásával ugyan láthatóvá válnak a vizsgált betegségre jellemző, az életminőséget vezérlő alskálák, ugyanakkor az individuális különbségek (az állapotban, és annak változásában is) széles megoszlása csak egyéni szinten válik értelmezhetôvé.

\section{Diszkusszió}

Közleményünk az első, amely magyar kohorszban, egy ritka, krónikus neuromuscularis betegségben, a Pompe-kórban vizsgálta a betegek által riportált

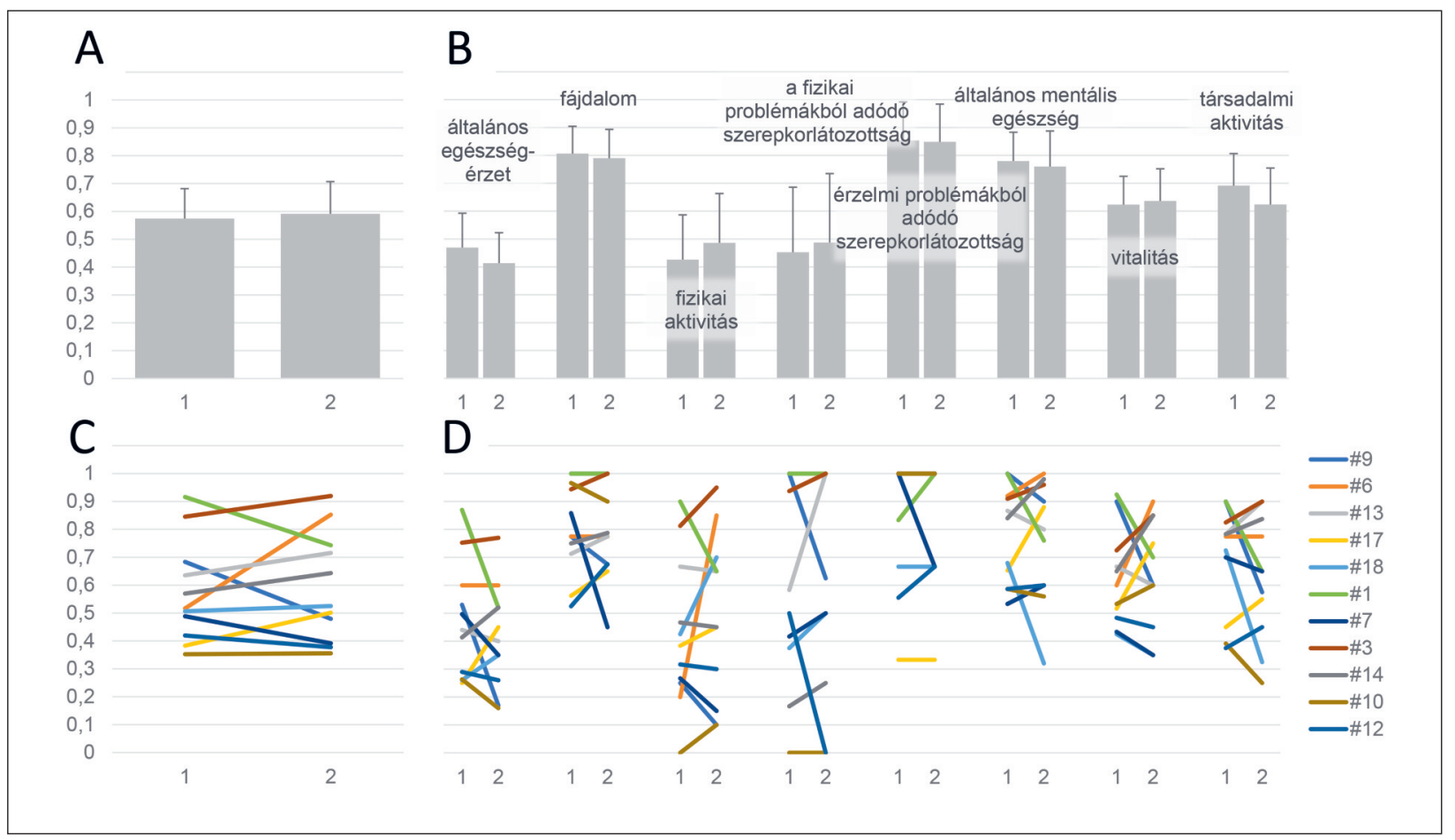

7. ábra. Az SF-36 pontszámok granularitásának jelentösége. Az SF-36 (36-item Short Form Health Survey) általános életminöséget mérö skála két időpontban, 3 év különbséggel felvett összesített pontszámai igen hasonlónak bizonyultak (A panel, az SF-36 kérdőív pontszámainak átlaga \pm 95\%-os megbízhatósági tartománnyal). Az egyes alskálákra bontás a betegségre jellemzó, súlyosabban érintett domének kiemelésére alkalmas (B panel). Az alsó sorban az összpontszámok (C panel), illetve az alskálákra bontott pontszámok egyéni szintú megjelenítése (D panel) mutatja be igazán az alskálákig részletezett adatok egyéni változatosságát 
kimeneti mutatókat, értékelte a PROM-ok hasznosságát egy hosszú távú innovatív kezelési modalitás, az enzimpótlás vonatkozásában. Vizsgálatunk egyértelmúen bizonyította, hogy az éveken át tartó kezelés megítélésében a hagyományos orvosi vizsgálat kiterjesztésével felvett 6 perces járástávolság, az MMT teszttel mért izomerô, a légzésfunkciót rögzító $\mathrm{FEV}_{1}$ és $\mathrm{FVC}$, valamint a laboratóriumi paraméterek mellett a PROM-oknak is fontos szerepe van mind a rövid, mind a hosszú távú követésben. Az objektív végpontok mellett ugyanis a PROM-ok segítségével a betegség új aspektusai is felismerhetők, és a betegségteher következtében kialakuló életminôség-romlás is jobban nyomon követhetô.

A PROM-oknak köszönhetően derült fény Pompe-betegségben a betegek szokatlan, az objektív izomerő-csökkenés mértékét meghaladó fáradékonyságára, ami vizsgálatunk adatai alapján is látható. Elsőként Yuan és munkatársai obszervációs tanulmánya közölte, hogy Pompe-betegeknél a kimerültség az izomgyengeség mellett az elsố tünetek egyike lehet ${ }^{13}$. Vizsgálatunkban a fáradékonyság a követés 3 éve alatt szinte minden betegnél fokozódott, még abban az esetben is, ha általános izomerejét stagnálónak minősítette az illetô. Egy másik érdekes megfigyelés a fájdalom kérdésköre volt, amelyre nem számítottunk egy tárolási anyagcserebetegségben. Egy tanulmány a PROM-ok értékelése során azt találta, hogy a Pompe-betegek fájdalma olyan általános tevékenységeket is negatívan befolyásol, mint a séta, a munka, a hangulat, az alvás és az élet élvezete ${ }^{14}$. Ebben a vizsgálatban a 124 részt vevő beteg $45 \%$-a számolt be fájdalomról. Az általunk gondozott Pompe-betegek esetében nem jelent meg a fájdalom olyan mértékú tényezőként, ami az életminőséget nagymértékben rontotta volna; nem zárható ki, hogy ennek hátterében a kohorsz mérete áll. A jelen PROM-adatok nagy része jól korrelált a korábbi megfigyeléseinkkel, melyeket a több mint 5 éve ERT-vel kezelt Pompe-betegeink állapotában figyeltünk meg a 6 perces járástávolságok és a légzésfunkciós vizsgálatok követésével ${ }^{15}$.

A betegségteher negatív hatását jól tükrözi, hogy a betegek a három év alatt a társadalmi aktivitásukat annak ellenére is romlónak ítélték meg, hogy fizikai aktivásuk átlaga javult. Az egyes alskálákra adott válaszok individuális elemzése elengedhetetlen, ugyanis itt fontos kérdésekre kaphatunk választ. A 7. ábrán az egyes betegek válaszainak vizsgálata kapcsán például feltûnik, hogy a világoskékkel jelölt (\#18) beteg a társadalmi aktivitás, a fáradékonyság és az általános mentális egészség tekintetében egyaránt romló pontszámokat adott meg, ezzel szemben fizikai aktivitását és a fizikai állapotát korlátozó hatásokat javuló pontszámokkal jellemezte. Ennek hátterében nagy valószínúséggel hangulatzavar áll, amit a betegségteher miatti dekompenzáció vagy exogén tényezók okoznak, mindenesetre a mintázat alapján kiszürésre kerülhet.

Kihívást jelentett, hogy a betegek motivációja nem volt egységes. Az adherenciát a távol eső kitöltési idôpontok negatívan befolyásolták, még úgy is, hogy a vizsgálat kezdetén ismeretterjesztő előadásban hívtuk fel a betegek figyelmét visszajelzéseik hasznára, és arra, hogy a PROM-ok kitöltésével ók maguk is aktív részeseivé válnak saját kezelésüknek, mivel az általuk szolgáltatott információk fontos adalékul szolgálnak az alkalmazott terápia hatékonyságának és az életminôségükben bekövetkező pozitív vagy negatív változásoknak a lemérésében. Meggyőződésünk, hogy megfelelően érzékeny, adaptív hozzáállással megtalálható a módja, hogy a betegek passzív szereplők helyett aktív részesei legyenek kezelésüknek. A Genomikai Medicina és Ritka Betegségek Intézetének munkatársai elkötelezettek a betegek ez irányú bevonását illetôen, és terveink között szerepel, hogy más ritka betegségcsoportra is kiterjesztjük a betegségspecifikus PROM-ok fejlesztését.

A jövőben a klasszikus kérdőíves PROM-ok mellett további modern technológiai lehetőségek is bevonhatók lesznek az állapot követésére. Ha információs technológiai eszközöket alkalmazunk az egészségi állapot megfigyelésére (például hordozható szenzorok, lépésszámláló, járásgyorsulás-figyelő, elektronikus naplók stb.), megvalósul a folyamatos, valós idejú utánkövetés.

\section{Következtetések}

A PROM-adatok a beteg által, az egészségügyi szakemberek és az egészségügyi szolgáltató felé közvetlenül riportált aktuális egészségi állapotot reprezentálják. Lehetőséget nyújtanak a beteg rutinszerú ellátás során megjelenő érzéseinek és állapotának komplex visszajelzésére, a kezelési lehetőségekkel kapcsolatos, a betegek számára is hasznos információ adására. PROM-mérések hiányában adataink nem tükrözik, hogy a betegek hogyan élik meg az egyes terápiás beavatkozásokat a mindennapi életben. Ahhoz, hogy ezek az adatok hasznosak legyenek, elengedhetetlen a PROMgyújtés, -elemzés és -jelentés módszereinek egységesítése, valamint a szabványos PROM-adatgyújtési eszközök elérhetősége. Egyre inkább kívánatos a valós evidenciák beépítése a szabályozási döntésekbe, a klinikai gyakorlatokra vonatkozó irányelvekbe és az egészségpolitikába. 
KÖSZÖNETNYILVÁNÍTÁS

Hálásan köszönjük Pompe-betegeink közremúködését a PROM-ok kitöltése során, valamint kezelöorvosaik támogatását. A Genomikai Medicina és
Ritka Betegségek Intézete az ERN NMD és ERN Rare Neurological Disorders tagja. A szerzók munkáját az FIKP és a Nemzeti Agykutatási Program 2.0 támogatta.

\section{IRODALOM}

1. Kish L. The blockbuster drug of the century: an engaged patient. HL7 Standards. (28 August 2012 accessed 6 July 2015). http://www.hl7standards.com/blog/2012/08/28/ drug-of-the-century/

2. Kingsley C, Patel S. Patient-reported outcome measures and patient-reported experience measures. BJA Education 2017; 17(4):137-44. https://doi.org/10.1093/bjaed/mkw060

3. Submitting Documents. Using Real-World Data and RealWorld Evidence to FDA for Drugs and Biologics. https:// www.fda.gov/media/124795/download

4. European Medicines Agency (EMA). RSS; "EMA Regulatory Science to 2025". https://www.ema.europa.eu/ en/documents/leaflet/ema-regulatory-science-2025-fivegoals_en.pdf

5. European Medicines Agency (EMA). Qualification of novel methodologies for medicine development. https:// www.ema.europa.eu/en/human-regulatory/research-development/scientific-advice-protocol-assistance/qualification-novel-methodologies-medicine-development

6. Food, U. S., \& Administration, D. Patient-focused drug development: Methods to identify what is important to patients: Draft guidance for industry, food and drug administration staff, and other stakeholders. Washington, D.C.: U.S. Food and Drug Administration. Submitting Documents.

7. Gnanasakthy A, Barrett A, Evans E, D'Alessio D, Romano C. A Review of patient-reported outcomes labeling for oncology drugs approved by the FDA and the EMA. (20122016) Health Policy Analysis 2019;22(2):203-9. https://doi.org/10.1016/j.jval.2018.09.2842

8. Calvert MJ, O'Connor DJ, Basch EM. Harnessing the patient voice in real-world evidence: the essential role of patientreported outcomes. Nature Reviews Drug Discovery 2019;
18:731. https://doi.org/10.1038/d41573-019-00088-7

https://media.nature.com/original/magazine-assets/ d41573-019-00088-7/d41573-019-00088-7.pdf

9. Schoser B, Bilder DA, Dimmock D, Gupta D, James ES, Prasad S. The humanistic burden of Pompe disease: are there still unmet needs? A systematic review. BMC Neurol 2017; 17:202. https://doi.org/10.1186/s12883-017-0983-2

10. Priya HM, Kishnani S, Krusinska E, Gault J, Sitaraman S, Sowinski A, et al. Use of the patient-reported outcomes measurement information system (PROMIS ${ }^{\circledR}$ ) to assess late-onset Pompe disease severity. J Patient Rep Outcomes 2020;4:83. https://doi.org/10.1186/s41687-020-00245-2

11. Kenneth I, et al. Forced vital capacity and cross-domain late-onset Pompe disease outcomes: an individual patientlevel data meta-analysis. J Neurol 2019;266(9):2312-21. https://doi.org/10.1007/s00415-019-09401-1

12. van der Beek NA, et al. The Rasch-built Pompe-specific activity (R-PAct) scale. Neuromuscul Disord 2013 Mar;23 (3):256-64. https://doi.org/10.1016/j.nmd.2012.10.024

13. Yuan $M$, et al. Positive association between physical outcomes and patient-reported outcomes in late-onset Pompe disease: a cross sectional study. Orphanet J Rare Dis 2020; $15: 232$. https://doi.org/10.1186/s13023-020-01469-7

14. Güngör, et al. Pain in adult patients with Pompe disease: a cross-sectional survey. Mol Genet Metab 2013;109:371-6. https://doi.org/10.1016/j.ymgme.2013.05.021

15. Molnar MJ, et al. The long-term follow-up of enzyme replacement treatment in late onset Pompe disease. Ideggyogy Sz 2020;73(5-6):151-9. 